\title{
Documentation of the traditional Alas food in Southeast Aceh District, Indonesia
}

\author{
IMAM HADI SUTRISNO ${ }^{1, \bullet}$, ADI BEJO SUWARDI ${ }^{2}$, ZIDNI ILMAN NAVIA $^{3}$, BAIHAQI $^{4}$, \\ MUHAMMAD ARIF FADHILAH ${ }^{5}$ \\ ${ }^{1}$ Department of History Education, Faculty of Teacher Training and Education, Universitas Samudra. Meurandeh, Langsa, Aceh, Indonesia, "email: \\ hadi_sutrisno@unsam.ac.id \\ ${ }^{2}$ Department of Biology Education, Faculty of Teacher Training and Education, Universitas Samudra. Meurandeh, Langsa, Aceh, Indonesia \\ ${ }^{3}$ Department of Biology, Faculty of Engineering, Universitas Samudra. Meurandeh, Langsa, Aceh, Indonesia \\ ${ }^{4}$ Department of English Language Education, Faculty of Teacher Training and Education, Universitas Samudra. Meurandeh, Langsa, Aceh, Indonesia \\ ${ }^{5}$ Department of Indonesian Language Education, Faculty of Teacher Training and Education, Universitas Samudra. Meurandeh, Langsa, Aceh, Indonesia
}

Manuscript received: 29 June 2021. Revision accepted: 15 July 2021.

\begin{abstract}
Sutrisno IH, Suwardi AB, Navia ZI, Baihaqi, Fadhilah MA. 2021. Documentation of the traditional Alas food in Southeast Aceh District, Indonesia. Biodiversitas 22: 3243-3249. The indigenous and traditional foods of the Alas tribe have a long history and unique traditions that have been passed down for thousands of years. Unfortunately, food tradition is strongly intertwined with the health-related and therapeutic reasoning of food ingredients and preparation methods. However, changes in people's consumption patterns, which prefer fast food, lead to a decline in local knowledge of traditional foods, particularly among the younger generation. Therefore, the aim of this study was to document the traditional Alas food in Southeast Aceh District, Indonesia. The study was conducted in eight subdistricts of Southeast Aceh, Indonesia, namely Lawe Alas, Babul Rahmah, Tanoh Alas, Babussalam, Darul Hasanah, Lawe Bulan, Lawe Sumur, and Bambel subdistricts. The study enlisted 80 respondents (10 from each district) who were chosen at random. The interview was conducted using a questionnaire that covered the respondents' backgrounds, traditional food names, food composition, mode of preparation, and uses. A total of 16 traditional Alas foods were documented, including six types of traditional cuisine and 10 types of traditional snacks. All respondents recognized Manuk Labakh, Ikan Pacik Kule, Puket Megaukh, and Buah Khum Khum as traditional Alas foods. On the other hand, less than $25 \%$ of respondents were familiar with some other traditional Alas foods, such as Menekem. The Alas tribe has a great system in place for passing down traditional knowledge from generation to generation. A total of 24 plant species consisting of 21 genera and 14 families was used as traditional Alas food. The Alas tribe prepares a variety of foods from various plant species to maintain their health and contribute to conservation efforts.
\end{abstract}

Keywords: Traditional knowledge, ceremonies, traditional culinary, Alas tribe, Southeast Aceh.

\section{INTRODUCTION}

Indonesia is a mega-biodiversity country, not only in terms of plants and animals but also in terms of cultural diversity. Indonesia has 1,340 ethnic groups (The Central Bureau of Statistics 2021), each with its distinct cultural characteristics. Culture is closely connected to social life. The community who live in rural areas has a strong sense of culture and tradition. A region's identity is reflected in its culture. Each region has a specific or distinct culture that is not shared by any other region. Culture, which often encompasses both tangible and intangible values, includes knowledge, beliefs, art, law, morals, customs, and behaviors characteristic of societies (Abdulla 2018). Cultural factors are social norms, values, and beliefs passed down through generations within an ethnic group, are influenced by society's social structure, language, and religion (Cencen and Berk 2014).

The Alas tribe is one of the tribes in Aceh province that inhabit Tanah Alas in Kutacane, Southeast Aceh District. This tribe lives on edge of the Bukit Barisan ridge or along the Alas river banks. The Alas tribe has a variety of traditional practices, such as Turun Mandi (birth), circumcision, marriage, and death (Mutia 2020). Various cultural communities use a variety of plants for traditional ceremonies (Sutrisno et al. 2020), food (Navia et al. 2015; Elfrida et al. 2020; Navia et al. 2020a; Suwardi et al., 2020a; Suwardi et al. 2020b), and medicinal purposes (Suwardi et al. 2021). Glutinous rice (Oryza sativa L. var. glutinosa) and coconut (Cocos nucifera L.) have been widely used in the preparation of Indonesian traditional foods (Supartono et al. 2010; Rianti et al. 2018), as well as Curcuma longa, Alpinia galanga, Kaempferia galanga, Zingiber officinale, Allium cepa, and Allium sativum (Wakhidah and Silalahi 2019). Traditional food culture is an important cultural heritage that reveals information about a society's identity, lifestyle, eating patterns, and originality (Karaca and Karacaoglu 2016). Factors such as geographical location and historical developments of the communities affect the cuisine culture, encompassing the unique way of eating styles, dish types, and methods of cooking and preparing dishes in the regions (Yaris and Ozkaya 2015).

However, changes in people's consumption patterns, which prefer fast food, lead to a decline in local knowledge of traditional foods, particularly among the younger 
generation. The behavior of communities in selecting, using, and consuming foodstuffs daily, including the type of food and frequency of eating, is influenced by sociocultural factors in which they live (Baliwati et al. 2004). Income, education, urban or rural environment, family composition, occupation, ethnicity, beliefs and religions, health, nutrition education, food production and distribution, and social politics are factors that influence the formation of a family lifestyle (Eliska 2016). The aim of this study is, therefore, to document the traditional Alas food in Southeast Aceh District, Indonesia.

\section{MATERIALS AND METHODS}

\section{Study area}

Southeast Aceh District, Aceh Province, Indonesia is geographically located between $3^{\circ} 28^{\prime} 50.0^{\prime \prime} \mathrm{N}$ and $97^{\circ} 49^{\prime} 13.8^{\prime \prime} \mathrm{E}$, with an altitude range from 50 to $400 \mathrm{~m}$ asl. The area is located around the Bukit Barisan ridge, and is part of Gunung Leuser National Park, with hilly and mountainous topography. There are 104,110 men and 104,371 women in the total population of 208,481 in 2020 (The Central Bureau of Statistics of Southeast Aceh District 2021). Southeast Aceh District is dominated by Alas tribe as a local tribe, followed by immigrant tribes such as the Singkil, Aceh, Karo, Batak Toba, Gayo, Javanese, Minangkabau, Mandailing, Nias, and Aneuk
Jamee tribes (The Central Bureau of Statistics of Southeast Aceh District 2021). The study was conducted in eight subdistricts of Southeast Aceh, Indonesia, namely Lawe Alas, Babul Rahmah, Tanoh Alas, Babussalam, Darul Hasanah, Lawe Bulan, Lawe Sumur, and Bambel (Figure 1).

\section{Data collection}

The study enlisted 80 respondents (10 from each subdistrict) who were chosen at random (Table 1). The interview was conducted using a questionnaire that covered the respondents' backgrounds, traditional food names, food composition, mode of preparation, and uses. Each interview lasted between 30 and 60 minutes and was conducted face-to-face in the local language (Alas language).

\section{RESULTS AND DISCUSSION}

\section{Traditional Alas foods and preparation}

The Alas tribe, which is primarily an agricultural society, has retained its culture and traditions, which include a variety of traditional foods made from various plant species. From the eight sub-districts of Southeast Aceh, 16 traditional Alas foods were identified, including six types of traditional cuisine and 10 types of traditional snacks.

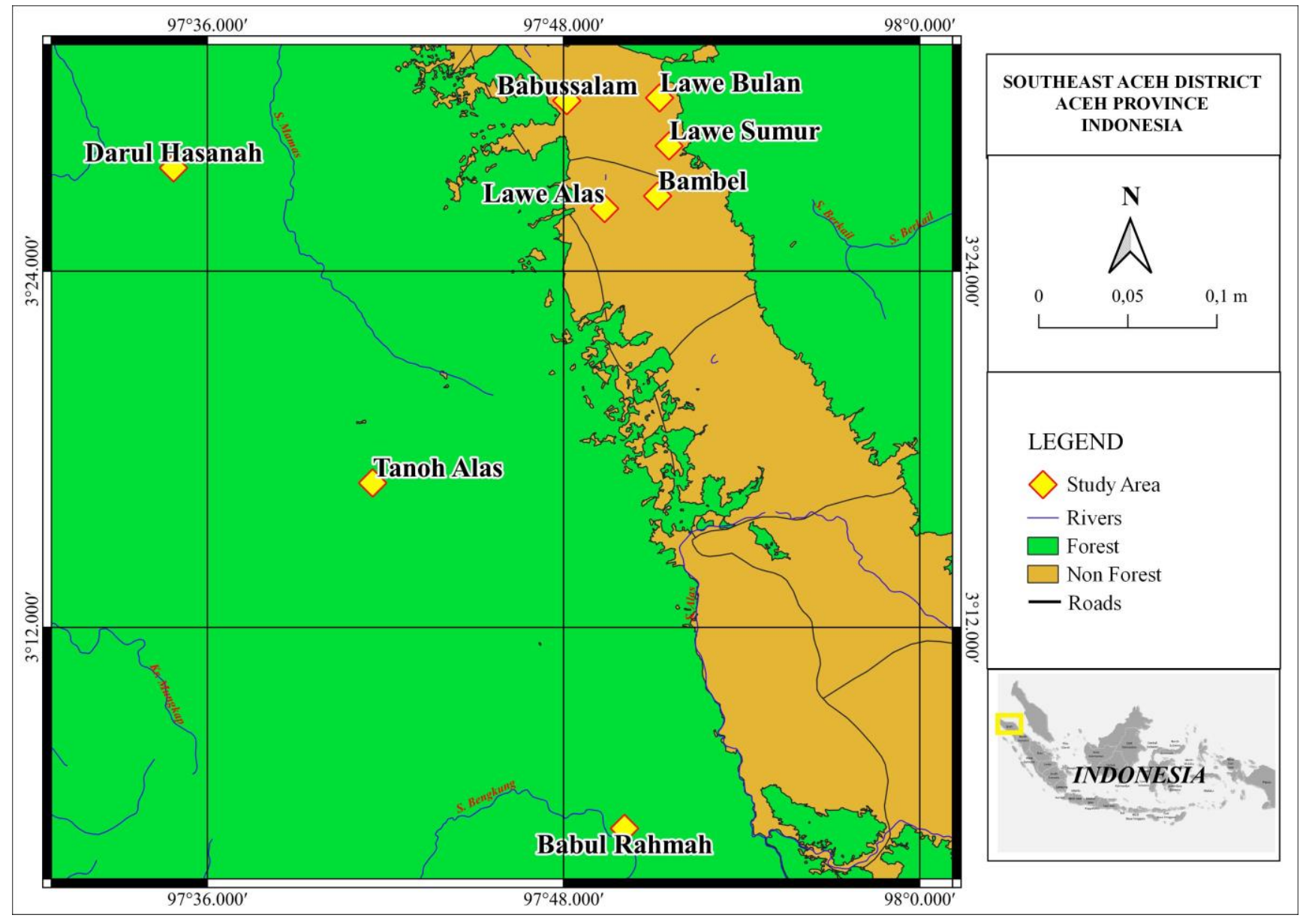

Figure 1. Map of Southeast Aceh District, Aceh Province, Indonesia, showing the study area 
Table 1. The demographic structure of respondents

\begin{tabular}{llcc}
\hline Parameter & Specification & Frequency & Percentage \\
\hline Gender & Male & 18 & 22.5 \\
& Female & 62 & 77.5 \\
Age & $15-25$ & 15 & 18.8 \\
& $26-35$ & 14 & 17.5 \\
& $36-45$ & 12 & 15.0 \\
& $46-55$ & 15 & 18.8 \\
Education & $56-65$ & 12 & 15.0 \\
& $>65$ & 12 & 15.0 \\
& Elementary School & 45 & 56.3 \\
& Junior High School & 14 & 17.5 \\
& Senior High School & 10 & 12.5 \\
& University & 11 & 13.8 \\
\hline
\end{tabular}

\section{Traditional cuisine}

Manuk Labakh

Manuk Labakh is a healthy food because it is prepared without using cooking oil. This food is frequently made with steamed or boiled duck or chicken. Several plants, including onion (Allium cepa), Coriander (Coriandrum sativum), pepper (Piper nigrum), lemongrass (Cymbopogon citratus), galangal (Alpinia galanga), lime (Citrus $\times$ aurantiifolia), and coconut (Cocos nucifera), are used as spices in Manuk Labakh. Manuk Labakh is typically served at a wedding or circumcision ceremony. According to our respondents, Manuk Labakh is believed to be able to prevent misery. Furthermore, the Alas tribe frequently employs this food to treat mimbar (magical diseases) caused by evil disorders.

\section{Sayukh Labakh}

Sayukh Labakh is a traditional Alas tribe cuisine that is still currently practiced. Golden fish, chicken, duck, and young fern (Diplazium esculentum) are the main raw materials for this cuisine. Spices used in this cuisine include coriander (Coriandrum sativum), lemongrass (Cymbopogon citratus), galangal (Alpinia galanga), ginger (Zingiber officinale), pepper (Piper nigrum), onion (Allium cepa), cumin (Cuminum cyminum), lime (Citrus $\times$ aurantiifolia), and coconut (Cocos nucifera). The main raw materials are boiled, while the spices are ground. The boiled main raw materials are then placed in a basin and mixed with the mashed spices. According to our respondents, Sayukh Labakh was invented in the $12^{\text {th }}$ century by the chief of the Alas kingdom as cuisine for the royal family.

\section{Ikan Pacik Kule}

Ikan Pacik Kule is a traditional Alas cuisine made from fish situ (Tor tambra Kotellat), a freshwater fish found only in the Lawe Alas river. This fish is prepared with a variety of spices, including turmeric (Curcuma longa), lemongrass (Cymbopogon citratus), galangal (Alpinia galanga), onion (Allium cepa), garlic (Allium sativum), red chili (Capsicum annuum), chili (Capsicum frutescens), lime (Citrus $\times$ aurantiifolia), candlenut (Aleurites moluccanus), coconut milk (Cocos nucifera), and salt. Clean and cut fish into medium-sized pieces, then season with salt and lime leaves and fruit. All spices are finely ground and evenly mixed. The fish is seasoned. Wrap the fish in pumpkin leaves (Lagenaria siceraria) and turmeric leaves. Arrange neatly in a skillet, add coconut milk and cook until dry. According to our respondents, at this time, Ikan Pacik Kule is more commonly prepared from goldfish (Cyprinus carpio). Ikan Pacik Kule was made using fermented fish in ancient times. Over time, the Alas tribe is intensely using fresh fish to make Ikan Pacik Kule.

\section{Tasak Telu}

Tasak Telu is a traditional food from Tanah Alas in Southeast Aceh. Tasak Telu is derived from the words "Tasak" (cooking) and "Telu" (three) in the Alas language. Tasak Telu determines to "three kinds of food" because the main spices used are chili (Capsicum annuum), lemongrass (Cymbopogon citratus), and onion (Allium cepa). Tasak Telu from the Alas tribe is almost identical to Karo cuisine from North Sumatra. The difference is due to the raw materials used. The Alas tribe uses duck meat, while the Karo tribe uses chicken meat.

Tasak Telu is a simple cuisine to prepare. Duck meat washed clean after being cut into pieces. This meat is boiled and seasoned with lemongrass (Cymbopogon citratus), galangal (Alpinia galanga), salam (Syzygium polyanthum), onions (Allium cepa), and garlic (Allium sativum). Add the asam sikala (Etlingera elatior), chili (Capsicum annuum), salt, and sugar once the duck meat is tender. Tasak Telu is all set to deliver.

\section{Menekem}

Menekem is a traditional Alas tribe cuisine that is rarely found in Southeast Aceh. Beef leg bones and beef ribs are the main ingredients in Menekem. Onion (Allium cepa), garlic (Allium sativum), lemongrass (Cymbopogon citratus), galangal (Alpinia galanga), asam sikala (Etlingera elatior), pepper (Piper nigrum), salt, and roasted coconut (Cocos nucifera) are among the spices used in this cuisine. The main ingredients are boiled, then seasoned with spices. The cooking time is approximately two hours. Menekem uses roasted coconut as a substitute for monosodium glutamate.

\section{Bakut Penget}

Bakut Penget is a traditional Alas cuisine made of catfish and ferns (Diplazium esculentum). Red chili (Capsicum annuum), chili (Capsicum frutescens), galangal (Alpinia galanga), lemongrass (Cymbopogon citratus), onion (Allium cepa), garlic (Allium sativum), turmeric (Curcuma longa), asam sikala (Etlingera elatior), lime (Citrus $\times$ aurantiifolia), coconut milk (Cocos nucifera), and salt are also used. To make this cuisine, combine catfish, ferns, and asam sikala in a pan, then add all the spices, coconut milk, lime leaves, and salt. The cooking time is approximately 1 hour. 
Traditional snacks

Puket Megaukh

Puket Megaukh is one of the Alas tribe's traditional foods made from glutinous rice (Oryza sativa var. glutinosa). This food is frequently served at traditional Alas tribal events as well as religious events such as weddings, circumcision, Prophet Muhammad's Birthday. Sugar palm (Arenga pinnata), Coconut milk (Cocos nucifera), and salt are also used as ingredients. Bring the coconut milk and salt to a boil, add the palm sugar, and mix until melted, after which add the glutinous rice and stir until evenly distributed. To improve the fragrance, Puket Megaukh is usually served in young banana leaves (Musa X paradisiaca).

\section{Lepat Bekhas}

Lepat Bekhas is a traditional Alas tribe that is especially popular during Eid al-Fitr. Furthermore, this food is frequently served as a fasting appetizer. Lepat Bekhas is made with white glutinous rice flour (Oryza sativa) and a variety of ingredients including pandan leaves (Pandanus amaryllifolius), durian fruit (Durio zibethinus), palm sugar (Arenga pinnata), sugar, salt, and coconut milk (Cocos nucifera). Glutinous rice is cooked with pandan leaves and coconut milk until half cooked and fragrant, then palm sugar, durian fruit, sugar, and salt are added and cooked until thick. The dough is then steamed after being wrapped in banana leaves.

\section{Gelame}

Gelame is an Alas tribe traditional food. Glutinous rice flour (Oryza sativa var. glutinosa), palm sugar (Arenga pinnata), coconut (Cocos nucifera), and pandan leaves (Pandanus amaryllifolius) are the main ingredients in this food. Making a small round dough with glutinous rice flour and water. Moreover, palm sugar and coconut milk are cooked, and pandan leaves are added. The Gelame dough is then soaked in a liquid made of palm sugar and coconut milk. Gelame is served as a required food during the rice planting ritual. Two days after the rice is planted in the fields, this ritual is performed.

\section{Buah Khum Khum}

Buah Khum Khum is a traditional sweet snack similar to Boh Romrom, which is popular in Aceh. This food is similar to kelepon, a traditional Javanese food. Buah Khum Khum is made with glutinous rice flour (Oryza sativa var. glutinosa), pandan leaves (Pandanus amaryllifolius), coconut (Cocos nucifera), palm sugar (Arenga pinnata), salt, and sugar. Pandan leaves are cleaned and blended, then glutinous rice flour, rice flour, and salt are added. Stir until completely combined. Take a small piece of dough, flatten it, and add palm sugar that has been combed, formed into small balls, and boiled. After that, the grated coconut is combined with sugar and salt. The Buah Khum Khum is drained and sprinkled with grated coconut. After that, it is now prepared to consume. Pandan leaves in Buah Khum Khum serve as a natural food coloring.

\section{Telukh Mandi}

Telukh Mandi is an Alas tribe traditional food made with glutinous rice as the main ingredient (Oryza sativa var. glutinosa). The method of preparation is glutinous rice mixed with coconut milk (Cocos nucifera), formed into a dough, and wrapped in banana leaves (Musa $x$ paradisiaca). This food is similar to lontong, a traditional food of the Javanese. During the month of Ramadan, the Alas tribe cooks this food.

\section{Keritip}

Keritip is an Alas tribe traditional food made with glutinous rice (Oryza sativa var. glutinosa) as the main ingredient. Glutinous rice is roasted until cooked, then soaked and combined with thawed palm sugar (Arenga pinnata). This food has a savory and sweet flavor that is ideal for an afternoon snack.

\section{Puket Mekuah}

Puket Mekuah is made from glutinous rice (Oryza sativa var. glutinosa), palm sugar (Arenga pinnata), and coconut milk (Cocos nucifera). The glutinous rice is mixed with coconut milk and filled with palm sugar. The dough is formed into an oval shape, wrapped in banana leaves (Musa $x$ paradisiaca), and steamed. Puket Mekuah is commonly served at the Alas tribe's traditional wedding ceremony.

\section{Puket Sekuning}

Puket Sekuning is a traditional Alas food composed of glutinous rice (Oryza sativa var. glutinosa), turmeric (Alpinia galanga), coconut (Cocos nucifera), and palm sugar (Arenga pinnata). Glutinous rice is made into a dough and steamed after being mixed with a turmeric liquid. Grated coconut is used to make a dough, which is then mixed with palm sugar and heated in a frying pan over low heat until cooked. Puket Sekuning is traditionally served on a banana leaf with grated coconut on top. Puket Sekuning is delivered at the kenduri rituals to pray for the souls of the deceased.

\section{Tumpi}

Tumpi is an Alas tribe traditional food. Glutinous rice flour (Oryza sativa var. glutinosa), palm sugar (Arenga pinnata), coconut milk (Cocos nucifera), and salt are used to make this food. All of the ingredients are combined to form a dough, which is then formed into a ball, flattened, and fried. This dish is frequently served at weddings and circumcision ceremonies.

\section{Cimpe}

Cimpe is a traditional snack made from rice flour that is very popular among the Alas tribe. This snack is also consumed by the Gayo tribe (Aceh) and Karo tribe (Tanah Karo, North Sumatra). The Gayo tribe calls it gutel, while the Karo tribe calls it cimpa unung. The preparation and serving method varies slightly for cimpé, cimpa unung, and gutel, but the ingredients are the same. Cimpa, for example, is wrapped in pandan leaves before steaming in the Alas tribe, whereas cimpa unung is wrapped in banana or palm 
leaves. Cimpe is made with rice flour (Oryza sativa), grated coconut (Cocos nucifera), palm sugar (Arenga pinnata), and sugar. All of the ingredients are combined evenly and formed into an oval shape. The dough is wrapped in pandan leaves (Pandanus amaryllifolius) and steamed for 20 to 30 minutes. Cimpe is a traditional snack that farmers frequently consume while working on a farm.

\section{Species composition of traditional Alas food}

A total of 24 plant species was used as traditional Alas food consisting of 21 genus and 14 families (Tabel 2). Zingiberaceae was the most represented plant family with four species, followed by Poaceae (three species), Amaryllidaceae, Apiaceae, Arecaceae, and Solanaceae species each. The other eight families have one representative species each.

The number of species recorded in this study (24 species) was lower than that in West Fujian, China i.e., 42 species (Luo et al. 2019), and 111 species in Lombok Island, Indonesia (Sukenti et al. 2016). However, it was higher than the 14 plant species reported in Turkey (Dogan et al. 2017), and 15 species reported in Lombok Island, West Nusa Tenggara, Indonesia (Rahayu and Ibo 2018).

\section{Traditional Alas food and human health}

Traditional Alas foods contain ingredients that have a positive correlation to human health. In their traditional foods, the Alas tribe uses a variety of plant species with medicinal properties. For example, the Alas tribe uses Etlingera elatior in their traditional cuisine. During the fieldwork, our respondents stated that the Etlingera elatior fruit is considered to be able to prevent hypertension. The mature fruits of Etlingera elatior were shown to have antihypertensive activities (Habsah et al. 2005). In addition, Etlingera elatior fruits are also traditionally used to treat earaches (Chan et al. 2007). Curcuma longa is also used in most of the traditional Alas cuisines. The rhizome is used as a flavoring in many cuisines and as a medicine to treat various ailments, including flatulence, jaundice, menstrual problems, hematuria, hemorrhage, colic, and can be used as an ointment to treat a variety of skin diseases (Labban 2014). Coconut milk is commonly used in traditional Alas cuisine and is assumed to encourage the maintenance of obesity. According to Hauy et al. (2020), coconut milk can reduce body weight, visceral fat, cholesterol, and triglycerides. Roasted coconut is used by the Alas tribe to substitute monosodium glutamate in food flavoring. According to our respondents, it can improve the taste of food while also being healthier. The Alas tribe prefers banana (Musa x paradisiaca) leaves to plastic as a food wrapper to maintain their health. According to our respondents, the use of plastic as a food wrapper, particularly for boiled foods such as Telukh Mandi, poses a health risk due to the presence of harmful compounds.

Table 2. List of plants used in traditional Alas food

\begin{tabular}{|c|c|c|c|c|}
\hline Botanical name & Vernacular name & Family & Use part & Habitat \\
\hline Aleurites moluccanus (L.) Willd. & Kemiri & Euphorbiaceae & Fruit & Farmland \\
\hline Allium cepa $\mathrm{L}$. & Bawang merah & Amaryllidaceae & Tuber & Home garden \\
\hline Allium sativum $\mathrm{L}$. & Bawang putih & Amaryllidaceae & Tuber & Farmland \\
\hline Alpinia galanga (L.) Willd. & Lengkuas & Zingiberaceae & Rhizome & Farmland \\
\hline Arenga pinnata (Wurmb) Merr. & Aren & Arecaceae & Fruit & Farmland \\
\hline Capsicum annuum $\mathrm{L}$. & Cabe merah besar & Solanaceae & Fruit & Home garden, Farmland \\
\hline Capsicum frutescens $\mathrm{L}$. & Cabe rawit & Solanaceae & Fruit & Home garden, Farmland \\
\hline Citrus $\times$ aurantiifolia (Christm.) Swingle & Jeruk nipis & Rutaceae & Leaves & Home garden \\
\hline Cocos nucifera $\mathrm{L}$. & Kelapa & Arecaceae & Fruit & Home garden, Farmland \\
\hline Coriandrum sativum $\mathrm{L}$. & Ketumbar & Apiaceae & Fruit & Farmland \\
\hline Cuminum cyminum L. & Jintan & Apiaceae & Fruit & Farmland \\
\hline Curcuma longa $\mathrm{L}$. & Kunyit & Zingiberaceae & Rhizome & Home garden \\
\hline Cymbopogon citratus (DC.) Stapf & Serai wangi & Poaceae & Leave & Home garden \\
\hline Diplazium esculentum (Retz.) Sw. & Pokis & Aspleniaceae & Leave & Farmland \\
\hline Durio zibethinus L. & Durian & Malvaceae & Fruit & Farmland \\
\hline Etlingera elatior (Jack) R.M.Sm. & Asam sikala & Zingiberaceae & Fruit & Farmland \\
\hline Lagenaria siceraria (Molina) Standl. & Labu sayur & Cucurbitaceae & Fruit & Farmland \\
\hline Musa x paradisiaca $\mathrm{L}$. & Pisang & Musaceae & Leaves & Home garden \\
\hline Oryza sativa $\mathrm{L}$. & Padi & Poaceae & Fruit & Farmland \\
\hline Oryza sativa $\mathrm{L}$. var. glutinosa & Pulut & Poaceae & Fruit & Farmland \\
\hline Pandanus amaryllifolius Roxb. ex Lindl. & Pandan wangi & Pandanaceae & Leaves & Home garden, Farmland \\
\hline Piper nigrum L. & Lada & Piperaceae & Fruit & Farmland \\
\hline Syzygium polyanthum (Wight) Walp. & Salam & Myrtaceae & Leaves & Farmland \\
\hline Zingiber officinale Roscoe & Jahe & Zingiberaceae & Rhizome & Home garden, Farmland \\
\hline
\end{tabular}




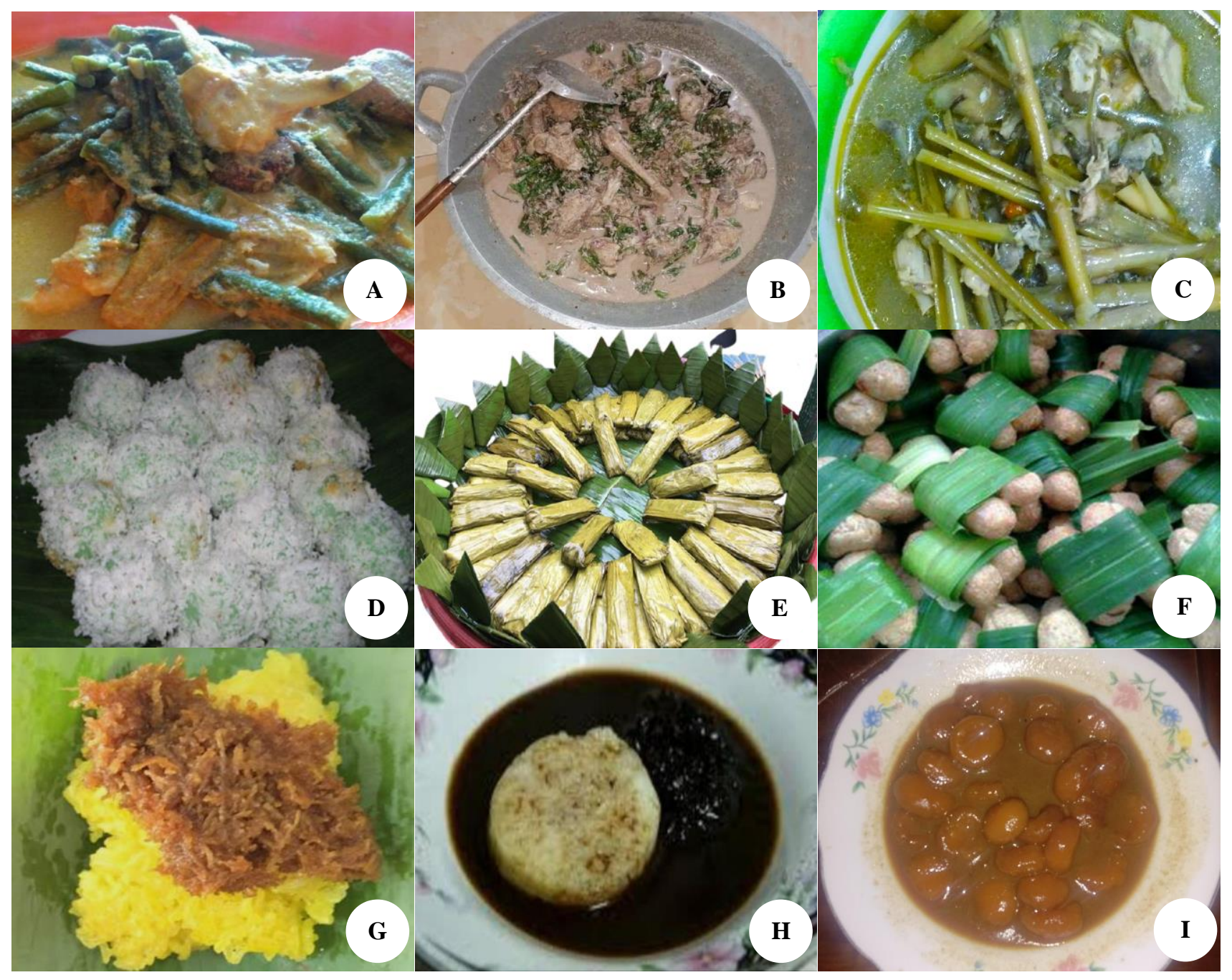

Figure 2. Traditional food of Alas tribe, Southeast Aceh District, Indonesia. A. Ikan Pacik Kule; B. Manuk Labakh; C. Tasak Telu; D. Buah Khum Khum; E. Cimpe; F. Puket Sekuning; G. Lepat Bekhas; H. Puket Mekuah; I. Telukh Mandi

The Alas tribe always uses a variety of plant species to prepare a variety of foods, including traditional foods. They believe that using natural ingredients can provide significant health benefits. The principles of the indigenous medical system are maintaining harmony between humans and nature and incorporating foods that nature provides to maintain the balance of bodily systems (Mihiranie et al. 2020). In addition to providing health benefits, the use of various local plant species can also be a conservation effort to ensure that these species do not become extinct in the future.

\section{Transfer knowledge among communities}

The Alas tribe's traditional knowledge in preparing and making traditional food has been transferred down through generations. Respondents to the study explained that knowledge of traditional foods was primarily acquired from parents and grandparents, accounting for 58\% of knowledge and ancestors accounting for $32 \%$. The average number of traditional Alas foods identified by respondents ranged from $16.3 \pm 1.12$ (15-25 years) to $22.12 \pm 0.03$ (>
65 years). Furthermore, the average number of traditional Alas foods identified by each respondent's educational status ranged from $11.3 \pm 2.11$ (Senior High School) to $22.14 \pm 3.10$ (Elementary School). All respondents recognized Manuk Labakh, Ikan Pacik Kule, Puket Megaukh, and Buah Khum Khum as traditional Alas foods. On the other hand, less than $25 \%$ of respondents were familiar with some other traditional Alas foods, such as Menekem.

The study found elders to be more knowledgeable about traditional Alas food. Elders are the custodians of knowledge, and they transfer their knowledge with such confidence that it will not be lost through generations (van der Hoeven et al. 2013; Suwardi et al. 2020c). Indigenous knowledge was primarily passed down from parents to the younger generation within communities (Ahmad and Pieroni 2016). Traditional knowledge, particularly traditional food preparation, has been passed down to the Alas tribe for a long time. Daughters have always been included in the preparation of traditional foods by their mothers. This study is consistent with Aqilah (2017) 
findings in Babah Dua Village, Aceh Jaya District, Aceh, Navia et al. (2020b) in Aceh Tamiang District, and Hakim et al. (2015) in Kopen Dukuh Village, Banyuwangi District, East Java. Several traditional foods, such as Manuk Labakh, have been commercialized. This activity is carried out in order to promote and preserve the existence of traditional Alas food in the future.

\section{ACKNOWLEDGEMENTS}

We are grateful to all people in the studied villages for their kind hospitality and share of knowledge. We are also grateful that the University of Samudra has supported this study.

\section{REFERENCES}

Abdulla MR. 2018. Culture, Religion, and Freedom of Religion or Belief The Review of Faith \& International Affairs 16 (4): 102-115. DOI: 10.1080/15570274.2018.1535033

Ahmad K, Pieroni A. 2016. Folk knowledge of wild food plants among the tribal communities of Thakhte-Sulaiman Hills, North-West Pakistan. J Ethnobiol Ethnomed 12: 1-15.

Aqilah CS. 2017. Ethnoecology and ethnobotany of spice plants Aceh community. [Thesis]. Bogor Agricultural University. [Indonesia]

Baliwati FY, Khomsan A, Dwiriani MC. 2004. Introduction to Food and Nutrition. Jakarta: Self-Help Publishers.

Cencen N, Berk NA. 2014. The place and the importance of the Turkish folk culture items at the 6th and 7th elementary social studies curricula. e-Kafkas J Educ Res 1 (3): 13e25.

Chan EWC, Lim YY, Omar M. 2007. Antioxidant and antibacterial activity of leaves of Etlingera species (Zingiberaceae) in Peninsular Malaysia. Food Chemistry 104 (4):1586-1593.

Dogan Y, Nedelcheva A, Pieroni A. 2017. The diversity of plants used for the traditional dish sarma in Turkey: Nature, garden and traditional cuisine in the modern era. Emirates Journal of Food and Agriculture. 29 (6): 429-440. DOI: 10.9755/ejfa.2016-09-1238

Elfrida, Mubarak A, Suwardi AB. 2020. The fruit plant species diversity in the home gardens and their contribution to the livelihood of communities in rural area. Biodiversitas 21 (8): 3670-3675.

Eliska, 2016. Pengaruh pola makan masyarakat suku Alas terhadap status gizi penderita hipertensi di wilayah kerja puskesmas perawatan kutambaru Kabupaten Aceh Tenggara. Journal of JUMANTIK 1(1): 25-41. [Indonesian] DOI: 10.30829/jumantik.v1i1.1014

Habsah M, Ali AM, Lajis N, Sukari M, Yap Y, Kikuzaki H. 2005 Antitumour promoting and cytotoxic constituents of Etlingera elatior. Malaysian Journal of Medical Sciences 12 (1): 6-12.

Hakim L, Batoro J, Sukenti K. 2015. Ethnobotany spices in the Kopen Dukuh Village of Banyuwangi Regency. Jurnal Pembangunan dan Alam Lestari 6 (2): 133-142. [Indonesian]

Hauy BN, Oliani CHP, Fracaro GG, Barbalho SM, Guiguer EL, de Souza MSS, Mendes CG, Bueno MS, Arau'jo AC, Bueno PCS. 2020 Effects of consumption of coconut and cow's milk on the metabolic profile of Wistar rats fed a hyper protein Diet. Journal of Medicinal Food 24(2): 1-4. DOI: oi.org/10.1089/jmf.2020.0031

Karaca OB, Karacaoglu S. 2016. Conceptual analysis of Arabian cuisine in the framework of culture, religion and food interaction: The case of Adana. Hitit Univ J Inst Soc Sci 9 (2): 561e84.

Labban L. 2014. Medicinal and pharmacological properties of Turmeric (Curcuma longa): A review. Int J Pharm Biomed Sci 5(1):17-23

Luo B, Li F, Ahmed S, Long C. 2019. Diversity and use of medicinal plants for soup making in traditional diets of the Hakka in West
Fujian, China. Journal of Ethnobiology and Ethnomedicine 15:60. DOI: $10.1186 /$ s13002-019-0335-y

Mihiranie S, Jayasinghe JK, Jayasinghe CVL, Wanasundara JPD. 2020. Indigenous and traditional foods of Sri Lanka. J Ethn Food 7: 42. DOI: 10.1186/s42779-020-00075-z

Mutia CR. 2020. Budaya lokal suku Alas "Pemamanan" sebagai bahan ajar Sastra. Linguistik 5 (2): 166-176. [Indonesian] DOI: 10.31604/linguistik.v5i2.166-176

Navia ZI, Chikmawati T. 2015. Durio tanjungpurensis (Malvaceae), a new species and its one new variety from West Kalimantan, Indonesia. Bangladesh J Bot. 44 (3): 429-436.

Navia ZI, Suwardi AB, Harmawan T, Syamsuardi, Mukhtar E. 2020a. The diversity and contribution of indigenous edible fruit plants to the rural community in the Gayo Highlands, Indonesia. J Agric Rural Dev Tropics Subtropics 121 (1): 89-98.

Navia ZI, Audira D, Afifah N, Turnip K, Nuraini, Suwardi AB. 2020 b. Ethnobotanical investigation of spice and condiment plants used by the Taming tribe in Aceh, Indonesia. Biodiversitas 21(10): 44674473.

Navia ZI, Suwardi AB, Nuraini. 2021. The importance of tropical edible fruit plants for tribal communities in East Aceh region, Indonesia. Earth and Environmental Science. 637 (1): 012003

Rahayu M, Ibo LK. 2018. Diversity of local food in Sasak Ethnic, Lombok Island, West Nusa Tenggara. Earth and Environmental Science 166: 012014. DOI: 10.1088/1755-1315/166/1/012014

Rianti A, Novenia AE, Christopher A, Lestari D, Parassih EK. 2018. Ketupat as traditional food of Indonesian culture. Journal of Ethnic Foods 5: 4-9. DOI: 10.1016/j.jef.2018.01.001

Sukenti K, Hakim L, Indriyani S, Purwanto Y, Matthews PJ. 2016. Ethnobotanical study on local cuisine of the Sasak tribe in Lombok Island, Indonesia. J Ethn Foods. 1-12. DOI: 10.1016/j.jef.2016.08.002

Supartono W, Mauna S, Guritno AD. 2010. Potency of Kipo, A Traditional Food from Kotagede-Yogyakarta. AGROINTEK 4(2): 128-131. DOI: 10.21107/agrointek.v4i2.1365.g1173

Sutrisno IH, Bachtiar A, Navia ZI, Nuraini, Suwardi AB. 2020. Documentation of ritual plants used among the Aceh tribe in Peureulak, East Aceh District, Indonesia. Biodiversitas. 21(22), 49904998.

Suwardi AB, Navia ZI, Harmawan T, Nuraini, Syamsuardi, Mukhtar E. 2020a. Ethnobotany, nutritional composition and sensory evaluation of Garcinia from Aceh, Indonesia. IOP Conf Ser Mater Sei Eng 725 (1): 012064.

Suwardi AB, Navia ZI, Harmawan T, Syamsuardi, Mukhtar E. 2020b. Wild edible fruits generate substantial income for local people of the Gunung Leuser National Park, Aceh Tamiang region. Ethnobotany research and applications 20: 1-13

Suwardi AB, Navia ZI, Harmawan T, Syamsuardi, Mukhtar E. 2020c. Ethnobotany and conservation of indigenous edible fruit plants in South Aceh, Indonesia. Biodiversitas 21(5): 1850-1860.

Suwardi AB, Mardudi, Navia ZI, Baihaqi, Muntaha. 2021. Documentation of medicinal plants used by Aneuk Jamee tribe in Kota Bahagia Subdistrict, South Aceh, Indonesia. Biodiversitas 22 (1): 2085-4722.

The Central Bureau of Statistics. 2021. Indonesia Statistics 2021. The Central Bureau of Statistics of Republic Indonesia.

The Central Bureau of Statistics of Southeast Aceh District. 2021. Southeast Aceh district in figure 2021. The Central Bureau of Statistics of Southeast Aceh district, Indonesia.

Wakhidah AZ, Silalahi M. 2019. Ethnobotany of "Pandap": Traditional cuisine from Saibatin community in West Pesisir Regency, Lampung, Indonesia. Biological and Pharmaceutical Sciences 9 (2): 126-133. DOI: 10.30574/gscbps.2019.9.2.0210

Van der Hoeven M, Osei J, Greeff M, Kruger A, Faber M, Smuts CM. 2013. Indigenous and traditional plants: South African parents' knowledge, perceptions and uses and their children's sensory acceptance. J Ethnobiol Ethnomed 9: 78. DOI: 10.1186/1746-4269978.

Yaris A, Ozkaya FD. 2015. Development process of American cuisine culture. J Tourism Gastronomy Stud 3 (3): 90-101. 